\title{
PJOK learning model through playing activities to build student character: designing and developing stage
}

\author{
Mhd. Ashar ${ }^{1}$, Syafruddin ${ }^{2}$, Gusril ${ }^{3}$, Eri Barlian ${ }^{4}$ \\ 1234Universitas Negeri Padang, Padang - Indonesia, (mhd_ashar@yahoo.com)
}

\begin{abstract}
One effort that can be done to overcome the deterioration of character values is through PJOK education. PJOK learning model was deemed necessary to be developed so that learning can build character values. The preliminary study data were collected by using questionnaires and interviews, then analyzed using descriptive statistics and descriptive analysis. The preliminary study results show that the average test score from 50 students is 60.50 point with five sets of test materials, playing at school 60 point, playing outside of school 50 point, learners participation at play time 40 point, character of awake learners 30 point and problem faced when playing 70 . The value of such data can be categorized very low and the authors conclude that it is necessary to design a learing model of sport and health education subject to construct character value of elementary school students. Based on the results of preliminary studies the authors try to design and develop PJOK learning model through playing activities to build student character values. The type of research used is Research and Development (R\&D) with procedure is Analyze, Design, Development, Implementation, Evaluation (ADDIE).
\end{abstract}

Keywords: PJOK learning, Designing, Developing.

\section{Introduction}

The development of today is so rapid. Science and technology are very helpful in doing things to make things easier. It turns out that technology also makes changes in the field of play. Children's play activities as well as learners at school are now beginning to be abandoned. Learners are now more fond of technology-friendly games, they love games like console games, online games on the internet, or games in shopping centers. In line with the various activities of play are sidelined above also coupled with the decline of the character of learners both at home and at school.

Education is the whole effort to influence the formation and formation of personality, including behavior change. That is, a well-executed and integrated education, will be able to nurture and form a good personality and character, so that good behavior can be maintained.

In line with the above, the subject of Physical Education of Sport and Health (PJOK or Penjasorkes), in the implementation of learning always involves the social dimension, in addition to physical criteria that emphasize skills, agility and performance "skill". This social dimension involves relationships among people, among learners as well as between educators as facilitators. The most 
appropriate learning model for exploring the potential and characterizing the learner is an explorative model. So that success and failure are not solely measured by intellectual instruments. Physical education and sports as a means of educating learners, providing an enrichment in ethics and morals in society. Teaching ethics and moral values should be more exemplary. Action is better than words. The moral values are various, including loyalty, virtue, honor, truth, respect, friendliness, integrity, justice, cooperative and discipline. Self-discipline is important in every effort to build and shape a person's character.

According to Bafirman (2012: 2), in the history of the nation's journey, Indonesia once had a wealth of character, the nation that has the character of a fighter, has gotong-royong culture, friendly nation, believes in God Almighty, a civilized nation and has a spirit of kinship. However, the State and all institutions, including religion have so far not succeeded in social engineering or transformation so that this social capital does not turn into a strong work ethic with noble moral and ethical joints.

Further, Bafirman (2012), explains that, the values of civilization have been reduced by the attitudes of savage barbarity in the form of student brawl, student brawl and brawl between citizens, rape, murder, mutilation, suicide, abortion, in crime and corruption, overcoming violence with violence and various vandalistic behaviors, such as: burning fires of government offices in defeat of pilkada, public disruptive demonstrations, audience behavior in certain arbitrary or blind games and so on.

In the formation of the character of learners, it is necessary role of teachers who can influence the character of learners. Teachers help shape the character of learners. This includes examples of how the teacher behaves, the way the teacher talks or conveys the material, how the teacher is tolerant, and other related matters. In the concept of learning, efforts to increase the character ideally can be done by all teachers. Kemendiknas, (2011), character education is implemented through three kinds of strategies, namely by integrating in the subject, own curriculum in the form of local content and also carried out in self-development activities.

The character of the learner as understood, is the process of planting the values of characters that are expected to be attached to the students themselves. This is certainly not an easy thing, but it will be very many components that support it. Based on the observation on 04 and 05 October 2016 that the writer did in some elementary school (SD) in Pasaman Regency, education mostly implemented at the teaching stage, that is as a transfer of science, which only emphasize the cognitive domain only, there is no learning model that can increase character of learners in Elementary School of Pasaman Regency. So that expected behavior change is not achieved.

Character is very important and is the goal of government policy and national education. Furthermore, Linckona, (2012) develops important character values to possess and internalize into learners and be integrated into learning. These values are: (1) Wisdom, (2) Justice, (3) Courage, (4) Self-control, (5) Love, (6) Positive Attitude, (7) Hard Working, (8) Integrity, 9) Gratitude, (10) Humility. (Linckona, 2012).

Gusril (2006) stated that learning that is not well prepared will make it difficult to achieve the basic competencies and competence standards required for primary school students who have an interest in playing activities. This will certainly lead to various reactions from learners such as, fighting, mutual mockery, because the learning process is not well managed.

\section{Method}

The research method used is descriptive quantitative method, Sample set 50 students of class V elementary school from three schools with probability sampling technique. Preliminary study data were collected by using questionnaires and interviews, then the data were analyzed using descriptive statistics and descriptive analysis. 


\section{Result and Discussion}

In the observations and interviews that researchers do, most learners say that the value of the character is an important. This they stated because the characters will be used not only in school but important where they are. Educators (teacher penjasorkes) also suggests the need for character values built primarily in the level of primary school students, so that after the great values of these characters can be used and internalized within the learners.

Learners also often get information about the importance of the character of parents and teachers, so as to build the value of the character in addition to the information presented to them, the way or method that is easily attached to the learners themselves for character learning, of course with the example of teachers and people adults around the child wherever they are.

The preliminary study process was conducted on the learning of pemasorkes in three elementary schools, namely: students of SD Negeri 05 Serasi Pasaman Regency (good category school), SD Negeri 01 Tarung-Tarung Pasaman Regency (medium category school), and SD Negeri 08 Lubuk Layang (school category less). The basic selection of schools to be tested with such a large group is based on three categories of schools taken on the basis of school rankings, school ranking data taken from the District Education Office Pasaman. This activity is carried out as an evaluation of the model tested. Target users of this product are elementary school students and teacher penjasorkes.

The preliminary study results show that the average test score of 50 students is 60.50 with five sets of test materials: Playing at school 60, Playing outside school 50, Participation of learners during play 40 , Character of learners who are awake 30 and Obstacles encountered during play 70 . The value of the data can be categorized very low and the authors conclude that the need to design a model of learning subjects PJOK or penjasorkes to build the character of primary school students peserda.

This design stage is done how to design the learning model of PJOK through play activities to build the character of learners. The design stage should be systematic and specific. Systematic means a logical, orderly method of identifying, developing and evaluating a set of planned strategies targeted to achieve the learning objective that is to enable learners' character to wake up. Specifically means every element of the instructional design plan needs to be run with attention to details. (2) supporting theories, and (3) guidance on the implementation of the learning model of the penjasorkes through play activities to build the character of the learners and include the things that into the main consideration or the basis of the importance of learning model penjasorkes through play activities to build the character of learners. Character design begins with core competency analysis and development of learning experiences, and evaluation. This is an important part to note.

According to the curriculum document book of 2013 Core competence is a translation or operationalization of Graduate Competency Standards (SKL) in the form of quality that must be owned by those who have completed education in a particular educational unit or a certain level of education. In this concept, core competency formulation is never separated from SKL that has been formulated. A description of the main competencies grouped into the attitudes, knowledge, and skills (affective, cognitive, and psychomotor aspects) that learners should learn for a school, class and subject. Core competence should reflect a balanced quality between the achievement of hard skills and soft skills that must be possessed by learners.

Learning experience is an important thing to develop in making character design learning. Researchers develop this learning experience as a major part in the development of learning models of penjasorkes through play activities to build character. Learning experiences are developed based on the results of analysis and input from educators (teachers PJOK or penjasorkes). Learning experiences are developed based on PJOK learning design or penjasorkes through the usual play activities performed by learners. 
This stage of development, is the process of realizing the learning model penjasorkes through play activities to build the character of elementary school students from the design stage into the real form. Learning model activity developed in this research is manifested in the form of guide / module, while the instructional model design is directed to the study to build the character of the students. Determine whether the cultural values and the listed characters are already included, then determine the value of characters to be developed in the lesson to design the lesson plan that includes the values of the characters, and integrate them with existing learning materials, develop the learning process actively, as well as compiling other learning tools such as materials, strategies, teaching materials and media, and conducted learning evaluation.

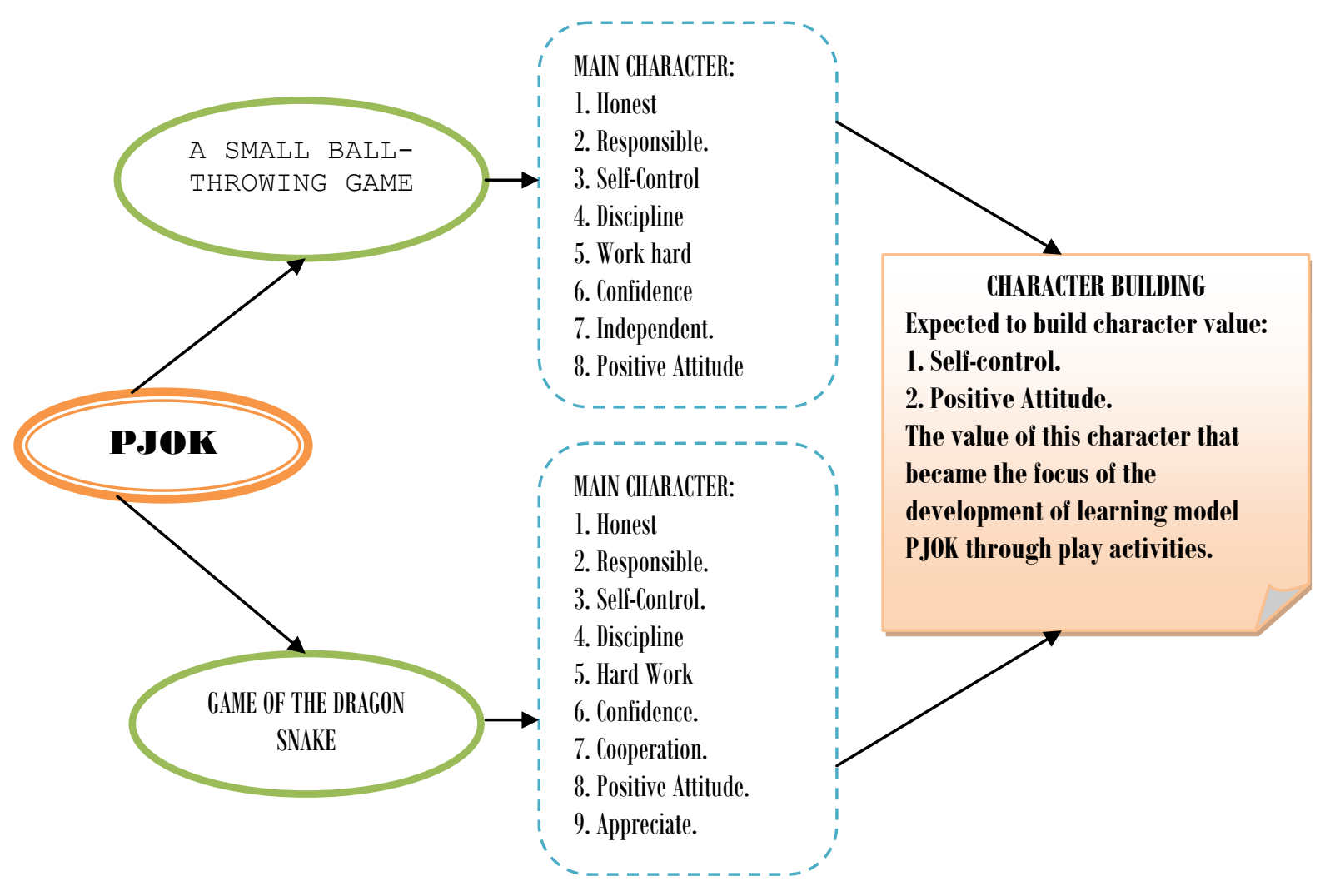

Figure 1 Plot builds characters through play activities.

In developing these early products also developed observation guidelines to observe the learning process of learners, as well as interview guides for learners and teachers who implement learning models penjasorkes to build character. The point is how the researchers actualize the design into the real form, as well as validation of the learning model by way of validating the content and constructs for the development of learning model PJOK through play activities produced more perfect.

Mulyasa (2011) explains, individuals who are good or superior character, is someone who tries to do the best things to God Almighty, himself, fellow, environment, nation and country and the international world, in general by optimizing the potential (knowledge) himself and accompanied by his awareness, his emotions and his motivations (his feelings). That is, the human character is a qualified human, in addition to trying to optimize the potential he has, he also strives to continue to benefit and optimize the practice of knowledge for others in the environment. In this case also need to be believed that, human character will always to avoid themselves from negative actions, which could harm himself and also others. The goal of character education is to form the behavior of learners who have the knowledge, skills, attitudes and behavior of noble character and have a 
competitive edge in facing globalization. In the context of globalization it is important to prepare students to be able to deal with these conditions.

Research conducted by Ermawan (2015) Character-based character education education to improve affective values in elementary school, the result of research in the form of modules developed in two kinds, the student's response after using the character-based learning module learning model shows that after using the learning model based on the characters above, most students can use this learning model. On the other hand, in the context of learning Olaraga Physical Education and Health (PJOK) developed so rapidly the various learning models that can develop the affective domain \{character). Personal and Social and Hellison (2003); Sport Education Model developed by Siedentop et al (2004); Cooperative Learning Model (Dyson, 2001), Teaching Values from Lumpkin (2008), Teaching Respect from Strais and Ruder (1996), and others.

Developing the character of learners can be done through the improvement and optimization of learning affective aspects of the subject of physical education Hansen (2008: 9) Affective domain more emphasis on the learning experience associated with emotions, such as attitudes, interests, concerns, awareness, directed value in the form of the realization of affective behavior. Tommie and Wend (1993) say some common themes appear in research related to the social psychology aspects of learning. However, based on observations that the authors do the characters have not been found attached to the students, especially Elementary School (SD). Ideal character formation starts from children of primary school age to be embedded until they grow up. At elementary school age is believed that the formation of moral will be easier because they have not been much affected by outside culture, and still easy to be given input to have a positive character.

\section{Conclusion}

The average test score of preliminary study of 50 students from several aspects measured is not good result, this implies the development of the character of learners in learning PJOK need to be developed, the results of preliminary analysis carried out that need to be developed learning model of PJOK through good play activity from aspects of book book models, guides and learning tools consisting of syllabus, RPP and teaching materials. The value of the data can be categorized very low and the authors conclude that it is necessary to design a model of learning subjects PJOK or penjasorkes to character building peserda educate primary school.

The data of the preliminary study analysis leads the writer to analyze the need to build the character of the elementary school students, which then poured into the form of rational learning design, supporting theories and model implementation instructions, thus becoming a learning model that builds character values, and also developed in the form of syllabus, RPP and teaching materials (learning devices) in the learning model PJOK or penjasorkes, in this case the development of products that build the character values of learners.

\section{References}

Andang, I. (2009). Education games a practical gaming guide that becomes your child smart, creative and pious. Jakarta: Gramedia.

Antonius A. gea et al. (2005). Charakter building 1, relationship with your self. Jakarta: Gramedia.

Bafirman, (2012). Character building and quality improvement of physical freshness through learning model of physical education of sport and health in elementary school. dissertation. Padang: State University of Padang.

Biddle, S., \& Whitehead, S. (2013). Adolescent girls' perception of physical activity: a focus group study. european physical education review, 4 (2), 243-262 http: www // 
journals.humankinetics.com/ jtpe-contents published in journal of teaching in physical education, volume 9, Issue 2, 2013.

Borg, W. \& Gall, M. (1989). Educational research: an introduction, fifth edition. New york: Longman. Gusril and Toho cholik mutohir. (2004). Motor development in children period. Jakarta: Directorate general of sports depdiknas.

Gusril. (2006). Motor development model in primary school students. research grant competing to. XIII funded by directorate general of higher education ministry of education 2005 and 2006. report. Padang: State University of Padang.

Gusril. (2016). Playing activities of elementary school students in Padang city. Padang: UNP press. Gusril. (2016). Motor development in the childhood. Padang: UNP press.

Lickona, T. (2012). Character matters. Jakarta: Earth literacy.

Lickona, T. (2013). Character education: a comprehensive guide to educating students to be smart and good (translated by: Lita. S). Bandung: Publisher nusa media.

Mulyasa, E. (2011). Character education management. Jakarta: Earth literacy. 